\title{
BIOLOGICAL COMPATIBILITY OF SOME TYPES OF ENDODONTIC CALCIUM HYDROXIDE AND GLASS IONOMER CEMENTS
}

\author{
BIOCOMPATIBILIDADE DE ALGUNS TIPOS DE CIMENTO ENDODÔNTICO À BASE DE \\ HIDRÓXIDO DE CÁLCIO E CIMENTOS DE IONÔMERO DE VIDRO
}

Marcia Carneiro VALERA ${ }^{1}$, Mário Roberto LEONARDO ${ }^{2}$, Alberto CONSOLARO ${ }^{3}$, Fábio da Silva MATUDA ${ }^{4}$

1- PhD Professor, Department of Restorative Dentistry, São José dos Campos Dental School, UNESP, São José dos Campos, SP, Brazil.

2- Chairman Professor, Department of Restorative Dentistry, Araraquara Dental School, UNESP, Araraquara, SP, Brazil.

3- Chairman Professor, Department of Pathology, Bauru Dental School, University of São Paulo, USP, Bauru, SP, Brazil.

4- Graduate student of Restorative Dentistry, São José dos Campos Dental School, UNESP, São José dos Campos, SP, Brazil.

Corresponding address: Fábio da Silva Matuda - Postgraduate student of Restorative Dentistry - Av. Paul Harris, 381- Jardim das Colinas São José dos Campos- São Paulo- Brazil - Cep.: 12.242-170 - Phone: + 551239234023 - Email: fabiomatuda@terra.com.br

Received: January 13, 2004 - Returned for modification: March 04, 2004 - Accepted: August 12, 2004

\begin{abstract}
$T$

The purpose of this work was to evaluate the biological compatibility of the Sealapex, Apexit, Sealer 26 and Ketac Endo endodontic cements. Polyethylene tubes containing these cements were implanted in the subcutaneous tissue of 40 (forty) rats. The animals were sacrificed after 14 and 90 days. A descriptive analysis of the reactions found in the connective tissue by contact with the cements was performed. The magnitude of inflammatory infiltrate, the presence and predominance of cell types and their distribution as to the filling material and reparative phenomena, such as fibroblastic and angioblastic proliferation and formation of fibrous capsules, were subjectively measured. After 90 days, all cements presented statistically significant reduction of the inflammatory reaction, presence of a fibrous tissue capsule in contact with the opening of the tubes containing the filling materials, and reduction of fibroblastic proliferation. Angioblastic proliferation decreased only for the Sealer 26 and Ketac Endo groups. All cements tested were either partially or totally phagocyted, and the mildest inflammatory response was found for the Sealer 26 group at both evaluation periods.

Uniterms: Endodontic cements; Calcium hydroxide; Biocompatibility; Glass ionomer cements.
\end{abstract}

\section{RESUMO}

Q

objetivo deste trabalho foi avaliar a biocompatibilidade dos cimentos endodônticos Sealapex, Apexit, Sealer 26 e Ketac Endo. Para isto, tubos de polietileno preenchidos com os quatros tipos de cimentos endodônticos foram implantados no tecido conjuntivo subcutâneo de 40 ratos. Os animais foram sacrificados após 14 e 90 dias. Primeiramente foi realizada a análise descritiva das reações encontradas no tecido conjuntivo em contato com os cimentos. A magnitude do infiltrado inflamatório, a presença e predominância de tipos celulares e sua distribuição com relação ao cimento empregado, os fenômenos reparativos, tais como proliferação angioblástica e fibroblástica e formação de cápsula fibrosa também foram subjetivamente quantificados. A análise dos resultados mostraram estatisticamente que todos os cimentos apresentaram após 90 dias redução de reação inflamatória, formação de cápsula fibrosa em contato com a abertura do tubo que continha o material de preenchimento e redução na proliferação fibroblástica. A proliferação angioblástica estava reduzida somente no grupo dos cimentos Sealer 26 e Ketac Endo. Todos os cimentos foram parcialmente ou totalmente fagocitados e a menor resposta inflamatória foi encontrada no grupo do cimento Sealer 26 em ambos períodos de avaliação.

Unitermos: Cimentos endodônticos, Hidróxido de cálcio; Biocompatibilidade, Cimentos de ionômero de vidro. 


\section{INTRODUCTION}

Both the physical and biological properties of endodontic cements must be considered. Calcium hydroxide has been added to endodontic cements in an attempt to obtain better biological properties ${ }^{1}$.

Glass ionomer cements have been developed on the basis of the studies of Wilson and Kent ${ }^{2}$. Glass ionomer is wellknown for its physical and chemical adhesion to tooth enamel and dentin ${ }^{3}$, allowing complete marginal sealing ${ }^{4}$ and biological compatibility ${ }^{5}$. With the development of Ketac Endo - a glass ionomer used for root canal filling - several researchers also evaluated the efficacy of such cements concerning apical sealing ${ }^{6,7}$.

The purpose of this study was to evaluate the connective tissue response to Sealapex, Apexit, Sealer 26 and Ketac Endo cements, placed in subcutaneous tissue of rats.

\section{MATERIALAND METHODS}

The root cements tested were (1) Sealapex (Kerr/Sybron) root canal sealer made of polymeric calcium hydroxide, (2) Apexit (Vivadent, Liechtenstein)-calcium hydroxide-based material, (3) Sealer 26 (Dentsply, Ltda.) - epoxy bisphenol resin and calcium hydroxide cement, (4) Ketac Endo (ESPE, Seefeld, Germany)-glass ionomer root canal cement.

Forty male, adult and genetically hybrid rats (Rattus Novergicus, Albinus, Wistar) weighing 180-220gr were used in the experiment. The animals were divided into two experimental groups with 20 rats each, with observation periods of 14 and 90 days, respectively.

The cements were prepared according to the manufacturers' recommendations. Afterwards, they were placed inside sterilized polyethylene tubes measuring $1.3 \mathrm{~mm}$ of internal diameter and $2 \mathrm{~mm}$ of external diameter, and these tubes were cut in sections of $10 \mathrm{~mm}$. Each tube was sealed at one of its ends.

The rats were anesthetized and underwent trichotomy of the dorsal area, followed by skin antisepsis with $0.3 \%$ iodized alcohol. The dorsal skin area was lifted with pincers and an incision of nearly two centimeters was made along the body of each animal. With straight thin-edged surgical scissors, penetrating through the incision, the subcutaneous tissue was dissected up to the point where the implants were placed.

A tube of each material was implanted in all animals. Two tubes were implanted at the scapular area, and the other two at the pelvic region. This way, four tubes were implanted in each animal, in an alternate system concerning the anatomical regions used. The incisions were closed and the animals were kept under observation.

After 14 or 90 days, the rats were anesthetized again. The implants were surgically removed together with a portion of surrounding tissue and placed in $10 \%$ neutral formalin solution.

After the fixation period, conventional laboratory procedures were performed until specimens were converted into paraffin blocks, each with a tube, material and surrounding tissues to be analyzed. Longitudinal microtomy was performed with a series of $6 \mu \mathrm{m}$ thick sections and stained by hematoxylin and eosin (HE). Microscopic evaluations were made with a Carl Zeiss Jena, Jenamed 2 model microscope with 10x, 40x and 400x objective lenses. The response of the connective tissue in contact with the cements tested was evaluated by analysis of the magnitude of inflammation, present and most predominant cell types, in addition to their distribution regarding the filling material. Further analysis addressed the reparative phenomena, analyzing fibroblastic and angioblastic proliferations and fibrosis. Density and organizational patterns of the fibrosis found in the material were observed. These patterns were subsequently analyzed to verify if they were in formation and if they were randomly distributed or displayed formation of capsule.

The information obtained on the inflammatory reaction and the reparative phenomena were registered in index cards and their magnitude was subjectively measured by using the score keys for the variables general inflammation magnitude and reparative phenomena: 0- Absent, 1- Mild, 2- Moderate and 3Intense.

The data obtained were statistically analyzed by a nonparametric H statistical Kruskal-Wallis model, to check whether there was any difference in the results due to the following factors: cement, time period, and interaction between the factors. The statistical model also verified whether there was any difference in the results due to the variables general magnitude of inflammation, fibroblastic and angioblastic proliferations, and density of fibrosis.

\section{RESULTS}

\section{Sealapex Group - 14 days (Figure 1A)}

At 14 days, disperse macrophages distributed on the peripheral area and next to the implant interacted intensively and directly with the filling material through dense phagocytosis. They presented normal size and cytoplasm impregnated with particles of the filling material, or sporadic cases of vacuolated cytoplasm. After phagocytosis, these cells either tended to remain at the peripheral area of the material, or migrated at random. Formation of typical granulomas also occurred in some regions.

Most specimens showed formation of inflammatory multinucleated giant cells (IMGCs), distributed close to the material and on its peripheral area. Their cytoplasm was generally impregnated with particles of the material and vacuolated in some specimens. The cells presented an average of 7 to 8 nuclei distributed at random.

Polymorphonuclear neutrophils (PMN), lymphocytes and plasma cells were found. Eosinophils were constantly present at the peripheral area of the material. Moderate fibroblastic and angioblastic proliferations were observed.

Fibrosis displayed a formation of capsule or random arrangement. 


\section{0 days (Figure 1B)}

During this period, a dense, weIl-formed granuloma with IMGCs permeating the material was observed. Macrophages and IMGCs either had vacuolated cytoplasm or were impregnated with particles of the material. The IMGCs presented an average of 10 nuclei.

A population of eosinophils was observed at the periphery of the central inflammatory region. Lymphocytes and plasma cells were found. The fibroblastic proliferation decreased, while the angioblastic proliferation remained moderate. A wellorganized and intense fibrous capsule was observed in all specimens.

\section{Apexit Group - 14 days (Figure 2A)}

This material showed predominantly mononuclear cellular infiltration. Macrophages were mainly located at the peripheral area and close to the cement and presented normal morphology and cytoplasm impregnated with the material, or vacuolated in many cases. In some specimens, these cells tended to assemble, forming typical granulomas, far from the opening of the tube. The IMGCs, when present, were situated near the material and exhibited cytoplasm impregnated with cement particles and 5

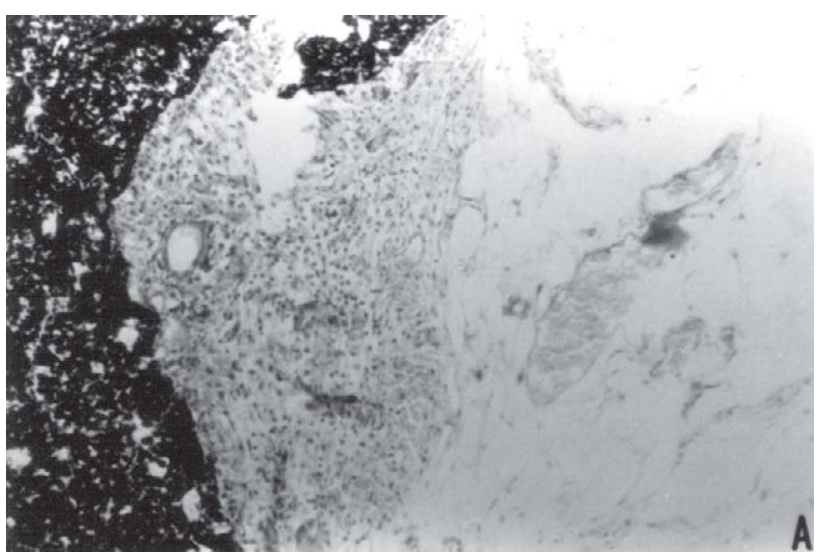

to 6 homogeneous or irregular-shaped nuclei. Neutrophils and lymphocytes were found within the filling material. Hyperemic vessels were also observed in various specimens. In some cases, the vascular congestion was intense.

Considering the reparative phenomena, both fibroblastic and angioblastic proliferations were moderate. Fibrous capsule of moderate intensity was located either around the material or at random.

\section{0 days (Figure 2B)}

The results were similar to those of the prior period, with a predominance of macrophages situated near and at the peripheral area of the material. These cells showed normal size and cytoplasm impregnated with particles or vacuolated.

The IMGCs, when present, were found close to the material, with cytoplasm impregnated with particles and 5 to 10 nuclei. In three cases, eosinophils and occasionally lymphocytes were also detected.

Both fibroblastic and angioblastic proliferations were moderate. A moderate to intense fibrosis formed a capsule around the material in some instances, with random arrangement in others.

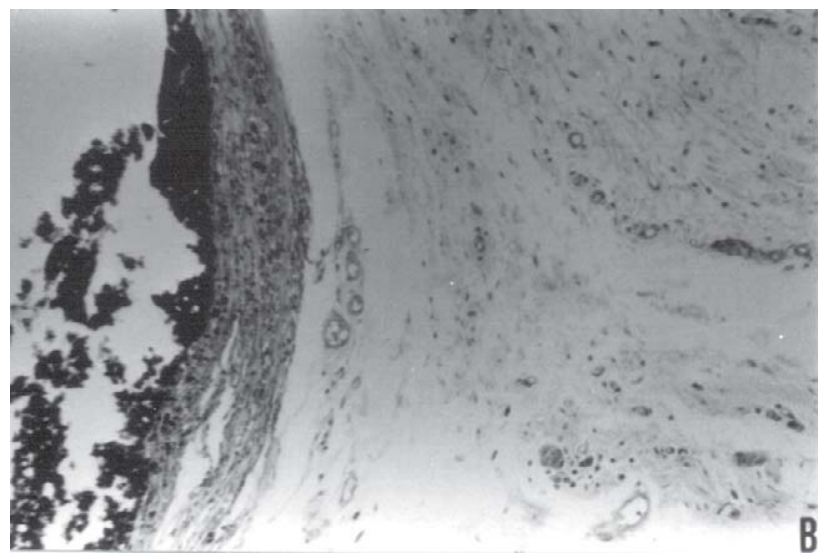

FIGURE 1- Response of the connective tissue in contact with Sealapex cement (arrows): 14-day experimental period (A) and 90-day experimental period (B). (40x)
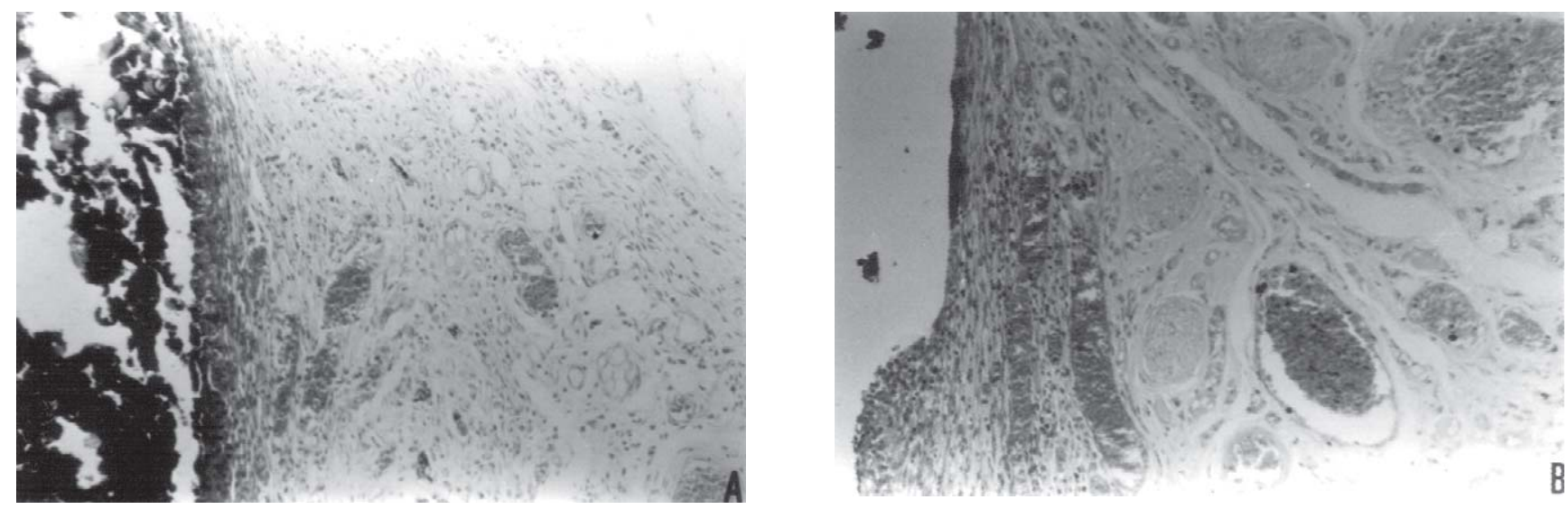

FIGURE 2- Response of the connective tissue in contact with Apexit cement (arrows): 14-day experimental period (A) and 90day experimental period (B). (40x) 


\section{Sealer 26 Group - 14 days (Figure 3A)}

The intensity of inflammation was mild and limited to a narrow zone close to the material. Macrophages were predominant and found near the material. Their cytoplasm was homogeneous, but impregnated with particles. In many cases, they invaded the spaces between parts of the material. In one specimen, formation of a typical foreign-body granulomatosis reaction was observed. The presence of IMGCs on the material surface, with an average of 8 to 10 nuclei, was seen in all specimens. PMNs were sporadic and only one of the specimens showed lymphocytes. Hyperemic vessels with mild congestion were observed in most specimens.

This group had mild fibroblastic and angioblastic proliferation. The latter event was moderate in some specimens. A moderate fibrosis, predominantly with formation of capsule, was observed.

\section{0 days (Figure 3B)}

Inflammatory reaction was almost absent at this period. Rare macrophages were observed around the peripheral area at the opening of the tube and showed a homogeneous aspect and cytoplasm with particles of the material. IMGCs had an

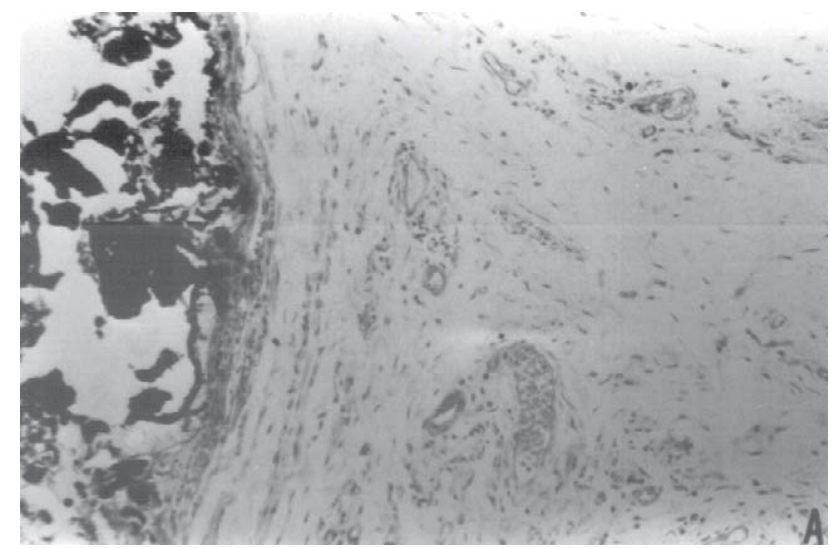

average of 5 nuclei, as well as cytoplasm impregnated with particles of the material.

Fibroblastic proliferation was mild, similar to that observed at the previous period, and angioblastic proliferation was not observed. Fibrous capsule was extremely dense in most specimens.

\section{Ketac Endo Group - 14 days (Figure 4A)}

Inflammatory reaction of the same magnitude was observed in all specimens. Foreign-body granulomas with groups of macrophages were formed at the peripheral area of the material. The cytoplasm of these cells was either vacuolated or impregnated with particles of the material.

Fibroblastic proliferation was mild, and angioblastic proliferation was moderate in all specimens. Fibrosis was mild and generally random.

\section{0 days (Figure 4B)}

The granulomatosis reaction to the material was reduced in magnitude and contact with the material. The macrophages showed normal size and cytoplasm impregnated with particles. IMGCs exhibiting cytoplasm impregnated with material particles

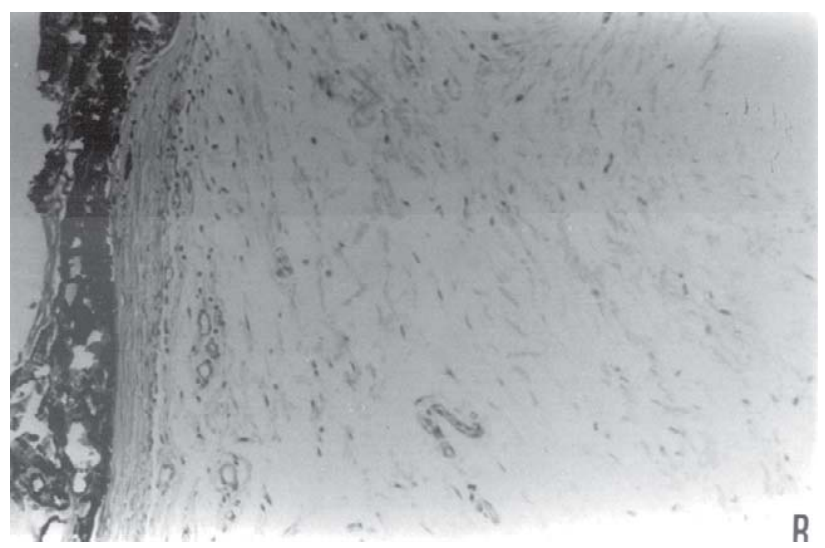

FIGURE 3- Response of the connective tissue in contact with Sealer 26 cement (arrows): 14-day experimental period (A) and 90-day experimental period (B). (40x)
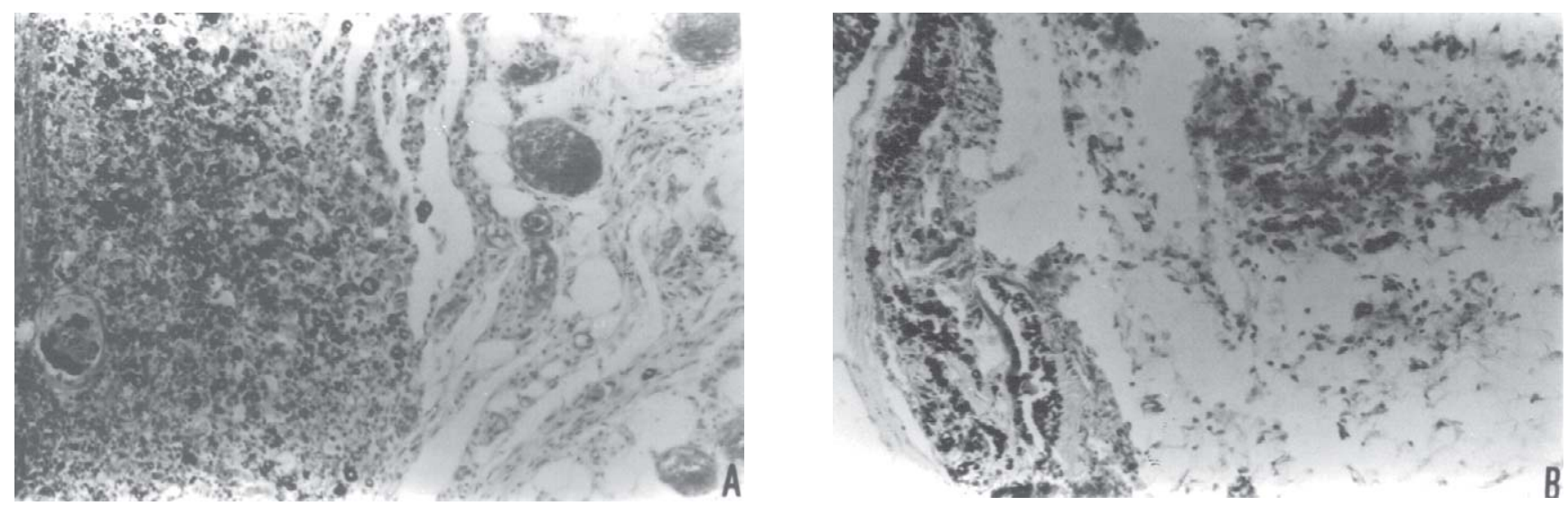

FIGURE 4- Response of the connective tissue in contact with Ketac Endo cement (arrows): 14-day experimental period (A) and 90-day experimental period (B). (40x) 
and an average of 5 nuclei were present in all specimens. Fibroblastic proliferation, when compared to the previous period, was mild to moderate in some specimens. Angioblastic proliferation was moderate in most specimens, but almost absent in some of them. Fibrosis was better organized in this period and exhibited formation of capsule around the material, with moderate or intense density.

\section{Statistical analysis}

The means for each material are registered in Table 1. Table 2 was obtained by application of the $\mathrm{H}$ statistics to the following variables: G.I.M., F.P., A.P., and F.D.

\section{DISCUSSION}

Cement implants placed in the subcutaneous tissue of animals evaluate the in vivo compatibility of materials to be used in extended contact with the connective tissues. The results of this method can be used as a preliminary source of information on the biocompatibility of endodontic cements. Therefore, tubes of different materials may be used as containers of the materials to be tested and implanted in animal tissues. Gutierrez, et al. ${ }^{8}$ used dentin tubes, while Zmener, et al. ${ }^{9}$ used silicone tubes. Holland, et al. ${ }^{10}$, Leal, et al. ${ }^{11}$ and Molloy, et al. ${ }^{12}$, on the other hand, used polyethylene tubes, since they had adequate size and shape and their lateral surfaces could be used as control. This statement is in accordance with the results of the present research, on which good tissue tolerance was observed in contact with the tube surfaces. An intense fibrous capsule was formed and was surrounded by apparently healthy tissue with no inflammatory cells. This characteristically normal tissue served as a control basis for this study.

The cements were immediately implanted after being prepared according to the manufacturers' instructions. An implant placed immediately after preparation of the cements may better reflect the normal clinical conditions. To avoid overflowing of the material, the material was held in the interior of the tube very carefully.

By microscopic analysis of the tissue reactions to the cements, the subjective quantitative and qualitative reactions were evaluated. The quantitative aspects of inflammatory reaction should not be prioritized in comparative microscopic evaluations of the inflammatory process. According to Molloy, et al. ${ }^{12}$, the subjective quantitative analysis of inflammatory phenomena, reparative phenomena and related reactions can provide reliable results, which may be used for evaluation of the cements being studied.

Analysis of the results of GIM (general inflammation magnitude) showed in Table 2 reveals that factors such as cement, time period and the interaction of these two variables presented a significant value of $\mathrm{H}_{0}(\mathrm{p}<0.05)$. It may be said that there were different tissue reactions considering the general inflammatory infiltration magnitude, when both periods (14 and 90 days) are compared. Thus, the inflammatory reaction at the 14-day period was more noticeable than that observed at the 90-day period (Table 1). The Sealapex cement showed an inflammatory reaction with macrophages being the predominant element and interacting intensively and directly with the material. At the 90-day period, a greater inflammatory reaction was observed when compared to that of the initial period. Zmener, et al. ${ }^{13}$ showed an increase of inflammatory reactions with the increase in the time period. Similar reactions were observed by Leal, et al. ${ }^{11}$, Birman, et al. ${ }^{14}$, Molloy, et al. ${ }^{12}$, and Holland and Souza ${ }^{15}$; however, this reaction was observed only when this particular cement was overflown to the periapical tissues in root canal fillings in dogs. In 1988, Tronstad, et al. ${ }^{16}$ verified that the Sealapex cement was removed from the interior of the polyethylene tubes and was replaced by a connective tissue containing macrophages with cytoplasm impregnated with particles. However, in the present experiment, the cement remained in the interior of the tube, where only the particles under phagocytosis were carried by the macrophages.

On the other hand, Yelsilsoy, et al. ${ }^{17}$ observed the appearance of calcifications in the connective tissue, and Leonardo, et al. ${ }^{18}$ observed apical and periapical repair after endodontic treatment. Valera ${ }^{19}$ studied the characteristics of the endodontic cement surface immediately after root canal filling and after a 6-month contact period with human blood plasma. The results obtained showed that the Sealapex cement was easily disintegrated after six months. This particular property of the Sealapex cement implies that a subsequent liberation of the residual products of this disintegration does

TABLE 1- Means of the variables general inflammation magnitude (G.I.M.), Fibroblastic proliferation (F.P.), Angioblastic proliferation (A.P.), and Fibrosis density (F.D.)

\begin{tabular}{l|llllllll}
\hline & \multicolumn{9}{|c}{ 14 days } & & \multicolumn{2}{c}{90 days } \\
Variables & \multicolumn{9}{|c}{} & & & & \\
\hline Material & G.I.M. & F.P. & A.P. & F.D. & GI.M. & F.P. & A.P. & F.D. \\
\hline Sealapex & 1.9 & 1.8 & 2.0 & 1.4 & 2.4 & 1.2 & 2.0 & 2.6 \\
Apexit & 1.9 & 1.7 & 1.8 & 1.7 & 1.5 & 1.4 & 1.9 & 2.4 \\
Sealer 26 & 1.1 & 1.2 & 1.4 & 2.2 & 0.8 & 1.0 & 0.5 & 2.8 \\
Ketac Endo & 2.8 & 1.0 & 1.9 & 1.0 & 1.5 & 1.3 & 1.5 & 2.5 \\
\hline
\end{tabular}


take place. These results are confirmed by the studies of Tagger, et al. ${ }^{20}$ and Leonard, et al. ${ }^{21}$, who verified considerable liberation of calcium ions from the Sealapex for an extended period of time, possibly due to its solubility. Despite the proved disintegration, a substantial concentration of macrophages impregnated with particles tends to accumulate around this type of cement. Although the inflammatory area is increased, there is no interference with its fibrosis and fibroblastic proliferation, as observed at the 90 -day period.
Among the four cements investigated in this study, Sealer 26 caused the mildest inflammatory reaction at both experimental periods. Inflammatory reactions with this cement were either reduced to a minimum, or were absent after the 90day evaluation period. The particles undergoing phagocytosis (black particles) during the first days had been either digested by the macrophages or had already moved away after the 90day experimental period. With Ketac Endo, the inflammatory response was significantly decreased after 90 days. Zmener

TABLE 2- $\mathrm{H}$ and $\mathrm{p}$ values observed according to the cements, time periods, interactions and multiple comparisons

\begin{tabular}{|c|c|c|c|c|c|c|c|c|c|}
\hline \multirow{2}{*}{$\begin{array}{l}\text { Source of } \\
\text { Variation }\end{array}$} & \multirow[t]{2}{*}{ DF } & \multicolumn{4}{|c|}{$\mathrm{H}_{0}$} & \multicolumn{4}{|c|}{$\mathbf{p}$} \\
\hline & & G.I.M. & F.P. & A.P. & F.D. & GI.M. & F.P. & A.P. & F.D. \\
\hline \multirow[t]{2}{*}{ Material } & 3 & 37.07 & 17.28 & 32.15 & $9.829^{*}$ & 0.000 & 0.000 & 0.000 & 0.020 \\
\hline & & $9^{*}$ & $2^{*}$ & $2^{*}$ & & & & & \\
\hline \multirow[t]{2}{*}{ Sealapex X Apexit } & 1 & $4.580^{*}$ & 0.218 & 1.653 & 0.074 & 0.032 & 0.640 & 0.198 & 0.785 \\
\hline & & & $\mathrm{n}$ & $\mathrm{n}$ & $\mathrm{n}$ & & & & \\
\hline \multirow[t]{2}{*}{ Sealapex X Sealer 26} & 1 & 25.51 & $6.907^{*}$ & 25.06 & $4.031^{*}$ & 0.000 & 0.008 & 0.000 & 0.043 \\
\hline & & $6^{*}$ & & $8^{*}$ & & & & & \\
\hline \multirow[t]{2}{*}{ Sealapex X Ketac Endo } & 1 & 0.024 & $5.268^{*}$ & 3.528 & 1.209 & 0.876 & 0.022 & 0.060 & 0.271 \\
\hline & & $\mathrm{n}$ & & $\mathrm{n}$ & $\mathrm{n}$ & & & & \\
\hline \multirow[t]{2}{*}{ Apexit X Sealer 26} & 1 & 16.41 & 11.92 & 18.77 & $6.264^{\star}$ & 0.000 & 0.000 & 0.000 & 0.012 \\
\hline & & $9^{*}$ & $1^{*}$ & $3^{*}$ & & & & & \\
\hline \multirow[t]{2}{*}{ Apexit X Ketac Endo } & 1 & $4.144^{\star}$ & $9.777^{*}$ & 0.294 & 1.770 & 0.042 & 0.001 & 0.588 & 0.183 \\
\hline & & & & $\mathrm{n}$ & $\mathrm{n}$ & & & & \\
\hline \multirow[t]{2}{*}{ Sealer 26 X Ketac Endo } & 1 & 25.10 & 0.272 & 13.51 & $8.721^{*}$ & 0.000 & 0.602 & 0.000 & 0.003 \\
\hline & & $2^{*}$ & $\mathrm{n}$ & $6^{*}$ & & & & & \\
\hline Interactions: Material/ & 3 & 27.07 & 22.97 & 5.218 & 22.04 & 0.000 & 0.000 & 0.156 & 0.000 \\
\hline Period - 14 days & & $2^{*}$ & $2^{* *}$ & $\mathrm{n}$ & $8^{*}$ & & & & \\
\hline Interactions: Material/ & 3 & 27.24 & $8.114^{\star}$ & 32.56 & $3.053^{\star}$ & 0.000 & 0.044 & 0.000 & 0.383 \\
\hline Period -90 days & & $1^{*}$ & & $0^{*}$ & & & & & \\
\hline \multirow[t]{2}{*}{ Period / Sealapex } & 1 & 2.451 & $7.492^{*}$ & 0.045 & $14.066^{*}$ & 0.117 & 0.006 & 0.832 & 0.000 \\
\hline & & $\mathrm{n}$ & 8 & $\mathrm{n}$ & & & & & \\
\hline \multirow[t]{2}{*}{ Period / Apexit } & 1 & 2.087 & 2.660 & 0.307 & $7.379^{\star}$ & 0.149 & 0.103 & 0.576 & 0.006 \\
\hline & & $\mathrm{n}$ & $\mathrm{n}$ & $\mathrm{n}$ & & & & & \\
\hline \multirow[t]{2}{*}{ Period / Sealer 26} & 1 & 2.452 & 3.461 & 17.70 & $4.169^{\star}$ & 0.117 & 0.063 & 0.000 & 0.041 \\
\hline & & $\mathrm{n}$ & $\mathrm{n}$ & $8^{*}$ & & & & & \\
\hline \multirow[t]{2}{*}{ Period / Ketac Endo } & 1 & 19.82 & $5.926^{\star}$ & 3.346 & 20.69 & 0.000 & 0.015 & 0.067 & 0.000 \\
\hline & & $0^{*}$ & & $\mathrm{n}$ & $0^{*}$ & & & & \\
\hline
\end{tabular}

* = significant difference $(p<0.05) ; n=$ non significant 
and Cabrini ${ }^{22}$, using cell culture, noticed fewer toxic effects when using a glass ionomer cement when compared to the utilization of other cements such as Diaket, Tubliseal and Fynal cements.

According to Causton ${ }^{23}$, as the glass ionomer cement comes into contact with humidity, an interruption in the cross connections of the gel matrix occurs, with subsequent disintegration of the cement during the first hours of solidification. This disintegration was confirmed by Valera ${ }^{19}$. Nevertheless, the present study revealed that the reparative processes continued, and after 90 days the formation of a thick fibrous capsule in contact with the material was also observed. It was noticed that reparative phenomena occurred parallel to and independent from the inflammatory reactions caused by the cements studied. It was also verified that the responses to the Sealer 26 and Sealapex cements were statistically better than for the Apexit and Ketac Endo cement, which were statistically equal. However, more studies are necessary on this aspect, in order to better explain the characteristics and alterations occurring with utilization of these cements at a shortterm period (immediately after filling) and at a long-term period.

\section{CONCLUSIONS}

Based on the present results, it can be concluded that all cements were either partially or totally phagocyted and allowed placement of a fibrous tissue capsule around the materials; however, the mildest inflammatory response was found at both evaluation periods.

\section{REFERENCES}

1- Berbert A. Behaviour of the periapical tissue after biopulpectomy and canal filling, with $\mathrm{AH} 26$, calcium hydroxide or a mixture of both. Bauru; 1978 (Thesis Bauru, School of Dentistry, Bauru, University of São Paulo, Brazil)

2- Wilson $\mathrm{AD}$, Kent BE. A new translucent cement for dentistry: the glass ionomer cement. Br Dent J 1972; 132:133-5.

3- Powis DR, Folleras T, Merson SA, Wilson AD. Improved adhesion of a glass ionomer cement to dentin and enamel. J Dent Res 1982; 61:1416-22.

4- McLean JW, Eilson Ad.. The clinical developement of glassionomer cement. 1. Formulation and properties. Aust Dent J 1977; 22: 31-6.

5- Snuggs HM, Cox CF, Powell CS, White KC. Pulpal healing and dentinal bridge formation in an acidic enviroment. Quintessence Int 1993; 24:501-10

6- Tidswell HE, Saunders EM, Saunders WP. Assessment of coronal leakage in teeth root filled with gutta-percha and a glass ionomer root canal sealer. Int Endod J 1994; 27:208-12.

7- Holland R, Sakashita MS, Murata SS. Effect of dentine surface tretment on leakage of root fillings with a glass ionomer sealer. Int Endod J 1995; 28:190-3.

8- Gutierrez JH, Gigoux C, Escobar F. Histologic reactions to root canal fillings. Oral Surg Oral Med Oral Pathol 1969; 28:557-66.
9- Zmener O, Cabrini RL. Adhesion of human blood monocytes and lymphocytes to different endodontic cements: a methodological in vitro study. J Endod 1986; 12:150-5.

10- Holland R, Souza V, Nery MJ. Behaviour of the subcutaneous connective tissue of the rat to the implant of polyethlene tubes filled partially or totally with some canal sealers. Rev Bras Odontol 1971; 28:197-201.

11- Leal JM, Holland R, Esberard RM. Sealapex, CRCS, Fill Canal and N. Rickert: biocompatibility study in the subcutaneous connective tissue of the rat. Odontol Clin 1988; 2:7-14.

12- Molloy D, Goldman M, White RR, Kabani S.. Comparative tissue tolerance of a new endodontic sealer. Oral Surg Oral Med Oral Pathol $1992 ; 73: 490-3$

13- Zmener O, Guglielmotti MB, Cabrini RL. Tissue response to an experimental calcium hydroxide-based endodontic sealer: a quantitative study in subcutaneous conective tissue of rat. Endod Dent Traumatol 1990; 6:66-72

14- Birman EG, Sampaio JMP, Magalhães J, Sato E. Study of some physical and biological properties of an endodontic sealer composed of calcium hydroxide. Rev. Odontol Univ São Paulo, 1990; 4:25-30.

15- Holland R., Souza V. Ability of a new calcium hydroxide root filling material to induce hard tissue formation. J Endod 1985; 11:53543.

16- Tronstad L, Barnett F, Flax M. Solubility and biocompatibility of calcium hydroxide- containing root canal sealers. Endod Dent Traumatol 1988; 4:152-9.

17.

18- Yesilsoy C, Koren LZ, Morse DR, Kobayashi C. A comparative tissue toxicity evaluation of established and newer root canal sealers. Oral Surg Oral Med Oral Pathol 1988; 65:459-67.

19- Leonardo MR, Silva LAB, Utrila LS, Assed S, Ether SS. Calcium hydroxide root canal sealers- hystopathologic evaluation of apical and periapical repair after endodontic treatment. J Endod 1997; 23: 428-32.

20- Valera MC. Study on the biological compatibility of some calciumhydroxide-based cements plus a glass ionomer cement. Evaluation of its apical marginal sealing capability and a morphological analysis of atomic strenght through microscopy. Araraquara; 1995. (Doctorate's Thesis (Endodontics). School of Dentistry of Araraquara. The "Júlio de Mesquita Filho" Paulista State University, Brazil).

21- Tagger M, Tagger E, Kfir A. Release of calcium and hydroxyl ions from set endodontic sealers containing calcium hydroxide. J Endod 1988; 14:588-90.

22- Leonardo MR, Reis RT, Silva LAB, Loffredo LCM. Calciumhydroxide in endodontics: an evalution of $\mathrm{pH}$ alteration and the liberation of calcium ions in calcium-hydroxide-based endodontic sealers. RGO 1992; 40:69-72.

23- Zmener O, Guglielmotti MB, Cabrini RL. Quantitative method for the study of the biocompatibility of the endodontic sealers in the subcutaneous connective tissue of the rat. Rev Assoc Odontol Argent $1988 ; 76: 27-34$

24- Causton BE. The physico-mechanical consequences of exponsing glass ionomer Wilson AD, Kent BE. A new translucent cement for dentistry: the glass ionomer cement. Br Dent J 1972; 132:133-5. 